\section{Første danske lærebok i palliativ medisin}

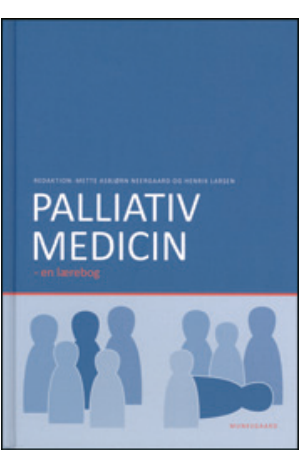

Mette Asbjørn Neergaard, Henrik Larsen, red. Palliativ medicin

En lærebog. 559 s, tab, ill. København:

Munksgaard, 2015. Pris DKK 475

ISBN 978-87-628-1226-0

Danskene har siden 2002 hatt en håndbok i palliativ medisin, i lommeutgave. I stedet for å revidere den bestemte de nye redaktørene seg for å utgi en lærebok. Boken er blitt til gjennom en nasjonal dugnad med 50 ulike forfattere. Med egen lærebok er det nå tatt enda et skritt $\mathrm{i}$ å fundamentere palliativ medisin som fag i Danmark.

Boken er delt inn i de fire delene Definisjon og organisering, Personlige, psykiske og relationelle temaer, Lindring af symptomer og tilstande og Palliation i forhold til diagnose. Del 1 er svært kortfattet. Del 2 fremstår som mest interessant, med gode, relativt fyldige kapitler om bl.a. kommunikasjon, etikk og jus. I del 3 presenteres imponerende mange symptomer og tilstander ved uhelbredelig sykdom, men de fleste kapitlene er svært summariske, og noen ganske overfladiske. Kapitlet om kakeksi er lite tilpasset palliative pasienter. Del 4 er også relativt summarisk, med stor variasjon mellom bidragene. Mens kapitlene om hematologi og hjertesvikt har en klar palliativ tilnærming, har kapitlene om geriatriske pasienter og demens nærmest utelukkende søkelys på medikamentell behandling, og får ikke frem bidraget til palliativ medisin i geriatri og sykehjemsmedisin.

Layouten er tiltalende, og forsiden er talende. Boken er oversiktlig og lettlest, med gode illustrasjoner og tekstbokser. Pasientperspektivet løftes frem ved at forfatterne systematisk legger vekt på de ulike symptomenes betydning for pasienten.

Jeg savner imidlertid en drøfting av palliativ medisin som fag palliativ tenkemåte, tilnærming og kultur, og hva dette faget spesifikt kan bidra med for de ulike sykdomsgruppene. Viktigheten av å gjenkjenne vendepunkter i sykdomsutviklingen er nærmest ikke beskrevet, noe som er grunnleggende for å kunne skifte hovedmålsetting fra livsforlengelse til vedlikehold av funksjon og videre til livskvalitet og lindring i siste livsfase. Muligens kommer dette stoffet i forlagets planlagte bok Den palliative indsats, som redaktørene hevder skal komplettere den foreliggende boken. Det burde likevel vært med her.

Disse anmerkningene til tross: Boken gir en god oversikt over legens oppgaver i det palliative feltet, og det meste er relevant også for norske forhold. Med korte, oppsummerende kapitler har boken en helt annen form enn Palliasjon. Nordisk laerebok, som snart kommer i ny utgave.

Målgruppen er leger i alle deler av helsetjenesten og medisinstudenter. Boken vil særlig være egnet som lærebok for medisinstudenter, og som en nyttig oppslagsbok for fastleger og annet helsepersonell som tar hånd om palliative pasienter.

Dagny Faksvåg Haugen

Seksjonsoverlege, Kompetansesenter i lindrande behandling Helseregion Vest

\section{Tankevekkende om våre mikropartnere}

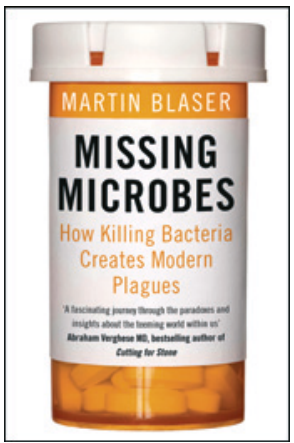

Martin Blaser

Missing microbes

How killing bacteria creates modern plaques.

275 s. London: Oneworld Publications, 2015.

Pris GBP 9

ISBN 978-1-78074-688-3

Professor Blaser er mikrobiolog, infeksjonsmedisiner og leder av det menneskelige mikrobiomprogrammet ved Universitetet i New York. Han har spesielt interessert seg for interaksjonen mellom vert og mikroorganismer. Han har blant annet brukt Helicobacter pylori som modell på hva som skjer med vår helse, ikke bare når vi koloniseres, men også når bakterier forsvinner. At $H$. pylori forsvinner er nemlig en markør for at også en rekke andre bakterier ikke lenger er med i vår mikrobiota.

Blaser er kjent for å tale hele det vitenskapelige og kliniske etablissementet imot med blant annet å hevde at $H$. pylori ikke kun er en patogen mikroorganisme (1). I 1990-årene var holdningen stort sett at «The only Helicobacter is a dead Helicobacter». Denne cowboyholdningen mener han var drevet av legemiddelindustrien som ville selge sine produkter. Hans gruppe fant senere at reflukssykdom og kreft i overgangen mellom spiserør og magesekk var vanligst hos de som ikke hadde $H$. pylori.

Med denne boken ønsker han å informere folk flest om risikoen ved overforbruk av antibiotika og hvordan det kan påvirke fremtidens medisin. Han hevder at mange av epidemiene $\mathrm{i}$ vårt moderne samfunn, slik som refluksøsofagitt, allergier, fedme, diabetes og inflammatoriske tarmsykdommer kan skyldes mangler i vår mikrobiota. Mennesker har gjennom tusener av år utviklet en mikrobiota som vi drar nytte av, og som beskytter oss mot sykdommer. I boken gir han en oversikt over oppdagelsen av ulike antibiotika, bruk og misbruk. Et gjennomsnittlig barn i USA får 11 antibiotikakurer før det har fylt 11 år uten at vi sikkert kjenner langtidseffektene. For øyeblikket selges $80 \%$ av all antibiotika i USA til bruk i landbruket, hvor det for det meste går til friske husdyr. Problemet går langt utover resistensutvikling. Antibiotika, advarer Blaser, ødelegger våre gode bakterier som vi behøver for god helse.

Blaser hevder at vår mikrobiota ikke lettvint kan erstattes med tilførsel av for eksempel bakteriekulturer i matvarer. Bakteriene som kun passerer gjennom tarmsystemet, har ingen varig effekt på immunapparatet. Han gir en fyldig begrunnelse for sine standpunkter ut fra klinisk forskning og laboratoriestudier, bl.a. gjennomført av hans egen stab. Beskrivelsen av hvordan vi oppdaget, nyttiggjorde og senere har misbrukt antibiotika, er meget lærerik og godt fremstilt.

Boken er svært leseverdig, oppsiktsvekkende og myntet på legfolk. Professor Blaser er nylig kåret blant verdens 100 mest betydningsfulle personer av tidsskriftet Time.

\section{Audun Elnæs Berstad}

Radiolog, Avdeling for radiologi og nukleærmedisin

Klinikk for diagnostikk og intervensjon

Oslo universitetssykehus, Rikshospitalet

\section{Litteratur}

1. Blaser MJ. Ecology of Helicobacter pylori in the human stomach. J Clin Invest 1997; 100: 759-62. 